\title{
NET BALANCE, SURFACE LOWERING, AND ICE-FLOW PATTERN IN THE INTERIOR OF LEWIS GLACIER, MOUNT KENYA, KENYA
}

\author{
By STEFan Hastenrath \\ (Department of Meteorology, University of Wisconsin-Madison, 1225 West Dayton Street, \\ Madison, Wisconsin 53706, U.S.A.)
}

\begin{abstract}
Observations obtained in a long-term monitoring program on Lewis Glacier, Mount Kenya, include measurements of net balance and velocity at a stake network over the period 1978-82, and airborne mapping of the glacier surface topography at the beginning and end of this interval. Horizontal and vertical flow components and mass continuity are evaluated along the longitudinal axis of the glacier.

The largest horizontal velocity at the surface is about $5 \mathrm{~m} \mathrm{a}^{-1}$, while the submergent vertical velocity at the surface in the upper, and the emergent component in the lower glacier are of the order of $1-2 \mathrm{~m} \mathrm{a}^{-1}$. Horizontal and vertical flow components in the interior of the glacier are calculated from the surface observations under plausible assumptions. Isotachs and streamlines plotted in a longitudinal-vertical cross-section permit the estimation of representative residence times of ice within Lewis Glacier. The largest values for the longest trajectories with submergence at the surface in the uppermost area of the glacier and emergence near the snout are of the order of a few centuries. However, such estimates are compromised, in particular, by the continuing nonequilibrium conditions of Lewis Glacier.

Mass continuity is directly related to the vertical motion field. In the upper area of the glacier the submergence velocity exceeds the rise of glacier surface observed with respect to the stake network, while in the lower glacier the emergent flow component falls short of the local negative net balance. This differing behavior of altitudinal zones is consistent with the fact that actual lowering of the glacier surface topography documented by the repeated airborne mappings is larger than expected from the stake network in the upper but less in the lower glacier. This differing behavior of altitude zones appears mitigated by the tendency for confluence in the upper and diffluence in the lower glacier.
\end{abstract}

Résumé. Bilan de masse, affaissement et écoulement dans la partie interne du Lewis Glacier, Mount Kenya, Kenya. Les observations recueillies au cours d'un programme á long terme sur le Lewis Glacier au Mount Kenya comportent des mesures de bilan de masse et de vitesse par un réseau de balises au cours de la période 1978-82 et une cartographie aérienne de la surface glaciaire au début et à la fin de cette période. On a évolué les composantes horizontales et verticales de l'écoulement et la conservation de la masse le long de l'axe longitudinal du glacier.

La plus forte vitesse horizontale en surface est d'environ 5 mètres par an tandis que la vitesse verticale en surface plongeante à l'amont, émergeante à l'aval du glacier est de l'ordre de 1 à $2 \mathrm{~m}$ par an. Les composantes horizontales et verticales de l'écoulement dans l'intérieur du glacier sont calculées à partir d'observations de surface au prix d'hypothèses plausibles. Les lignes d'égale vitesse et les lignes de courant dessinées dans une section longitudinale verticale permettent une estimation de la duree de subsistance de la glace dans l'intérieur du Lewis Glacier. Les plus fortes valeurs pour les trajectoires les plus longues avec enfouissement à la surface du haut de la zone d'accumulation et émergence près de la langue terminale sont de l'ordre de quelques siècles. Cependant ces estimations sont faussées, en particulier par la persistance de conditions de non équilibre du Lewis Glacier.

La conservation de la masse est en relation directe avec le champ des vitesses verticales. Dans la partie supérieure du glacier, la vitesse verticale plongeante dépasse l'élévation de la surface du glacier mise en évidence par le réseau de balises, tandis qu'à la langue terminale, la vitesse d'émergence compense en partie le bilan de masse local déficitaire. Ce comportement différent des zones selon les altitudes est cohérent avec le fait que la diminution réelle de l'altitude de la surface glaciaire, relevé par les missions aériennes est plus forte qu'on ne l'attendait d'après les réseaux de balises dans le haut mais moindre que prévue dans la partie basse. Ces comportements différents des zones d'altitude apparaissent tempérées par la tendance à la confluence dans le haut et à la diffluence dans le bas du glacier.

Zusammenfassung. Nettomassenbilanz, Absinken der Oberfläche und Eisflussmuster im Inneren des Lewis Glacier, Mount Kenya, Kenya. Das im Rahmen eines langfristigen Messprogramms auf dem Lewis Glacier am Mount Kenya gasemmelte Beobachtungsmaterial umfasst Messungen der Nettomassenbilanz und der Geschwindigkeit mittels eines Netzes von Pegeln über den Zeitraum 1978-82 und luftphotogrammetrische 
Kartierungen der Gletscherobefläche zu Beginn und Ende dieser Periode. Horizontale und vertikale Fliesskomponenten und Massenkontinuität werden entlang der Gletscherlängsachse ausgewertet.

Die grösste Horizontalgeschwindigkeit an der Oberfäche erreicht etwa $5 \mathrm{~m}$ pro Jahr, während die abwärts gerichtete Fliesskomponente im oberen und die aufwärts gerichtete Komponente im unteren Gletscher um 1-2 m pro Jahr betragen. Horizontale und vertikale Fliesskomponenten im Inneren des Gletschers werden aus Oberflächenbeobachtungen unter plausiblen Annahmen berechnet. In einem longitudinalen Vertikalschnitt aufgetragene Isotachen und Stromlinien erlauben eine Abschätzung der repräsentativen Verweilzeiten des Eises im Lewis Glacier. Die grössten Werte für die längsten Trajektorien, mit Subsidenz an der Oberfläche in den höchsten Gletscherlagen und Emergenz nahe dem Gletscherende, belaufen sich auf einige Jahrhunderte. Indessen sind solche Abschätzungen mit Unsicherheiten behaftet, die sich vor allem durch den andauernden Mangel von Gleichgewichtsverhältnissen am Lewis Glacier ergeben.

Massenkontimuität steht in direkter Beziehung zum Feld der Vertikalbewegung. In den höchsten Gletscherlagen übertrifft die Absinkbewegung die an den Pegeln beobachete Aufwärtsverlagerung der Gletscheroberfläche, wogegen in der unteren Gletscherregion die aufwärtige Fliesskomponente hinter der örtlichen negativen Massenbilanz zurückbleibt. Dieses nach Höhenzonen unterschiedliche Verhalten stimmt mit dem Unstand überein, dass die durch die wiederholte luftphotogrammetrische Vermessung belegte Verringerung der Eisdicke in den oberen Gletscherlagen grösser ist als nach den Pegelmessungen zu erwarten, während in den unteren Gletscherpartien das umgekehrte zutrifft. Dieses nach Höhenzonen unterschiedliche Verhalten erscheint gemildert durch die Tendenz zur Konfluenz im oberen und Diffluenz im unteren Gletscher.

\section{INTRODUCTION}

Results of a multi-annual field program of glacier and climate monitoring on Mount Kenya have been presented in a series of articles in this and other journals (Hastenrath, 1975; Caukwell and Hastenrath, 1977, 1982; Hastenrath and Caukwell, 1979; Hastenrath and Kruss, [1981], 1982; Hastenrath and Patnaik, 1980; Bhatt and others [1982]; Thompson and Hastenrath, [1982]; Kruss and Hastenrath, 1983). The monitoring program reached an important juncture in March 1982, when net balance and precipitation measurements made continuous over four mass-budget years were brought to a conclusion, an airborne mapping was carried out to match the chart obtained for the beginning of that four-year interval, and renewed electronic distance measurement (EDM) surveys of the stake network yielded further velocity determinations.

This ensemble of observations together with our earlier determination of ice thickness and bedrock topography (Bhatt and others, [1982]), allows the consideration in context of the net balance derived from the stake network, the surface lowering documented by the airborne mappings at the beginning and end of the four-year period, and the ice flow pattern in the interior of the glacier as deduced from surface observations, as well as the issue of representative residence times of ice in Lewis Glacier. Results pertinent to this problem complex are discussed in the present paper.

\section{OBSERVATIONS}

Components of the field program have been described before in various sources (Hastenrath and Caukwell, 1979; Hastenrath and Kruss, [1981]; Bhatt and others, [1982]; Caukwell and Hastenrath, 1982), so that this summary is limited to the information relevant to the present study.

Figure 1 shows the network of stakes installed in January 1978 for both net balance measurements and velocity determinations. Also included is the central line used as reference in 


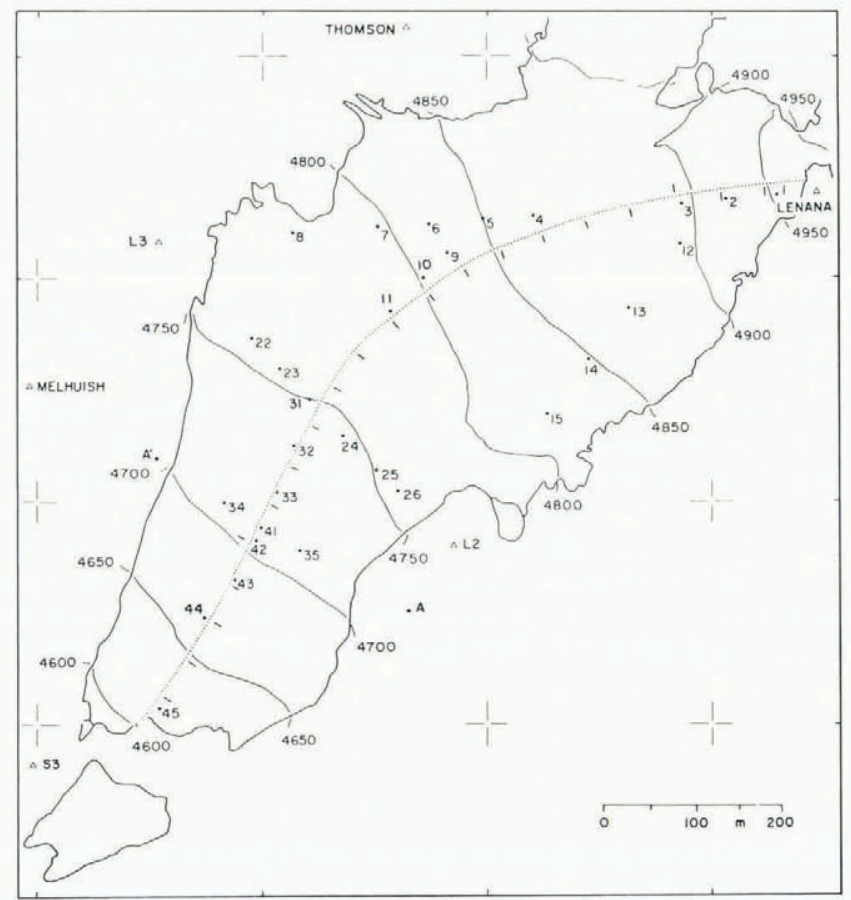

Fig. 1. Orientation map of stake network installed in January 1978. Height contours in metres are shown as solid lines. Dotted line indicates central line used as longitudinal axis of the glacier in Figs 5 and 6, with tick marks denoting $50 \mathrm{~m}$ intervals counted from the highest point of the glacier below Point Lenana. Scale is as the maps in Figs 2 and 3, and the horizontal scale in Figs 3 and 4.

various of our earlier studies. (This is adopted as the longitudinal axis in the longitudinal-vertical cross-sections of Figures 4 and 5.) Stakes in the vicinity of this central line are of primary interest in the present study.

Height changes of the glacier surface with respect to a fixed mark on the stakes are available for the complete four-year interval at some, but not all stations (this distribution being apparent from Figs 4 and 5). Height changes are commonly converted into liquid water equivalent net balance, but the unconverted quantities are of interest here. Figure 2 is a contour map of height changes observed at the stake network.

The horizontal and absolute vertical coordinates of the footpoint of stakes were determined during the various surveys using EDM equipment. Displacement over the entire four-year period is available for some, but not all, stations as indentified in Figures 4 and 5.

Airborne mappings of the ice surface topography at scale 1:2500 were produced for February 1978 and March 1982 (Hastenrath and Caukwell, 1979; Caukwell and Hastenrath, 1982). A comparison of these maps yields the chart of observed change in ice thickness over the four-year interval (Fig. 3).

Use is further made of the ice thickness and bedrock determinations reported in Bhatt and others, (1980). This forms the basis for the longitudinal bedrock profile sketched in Figures 4 and 5 . 


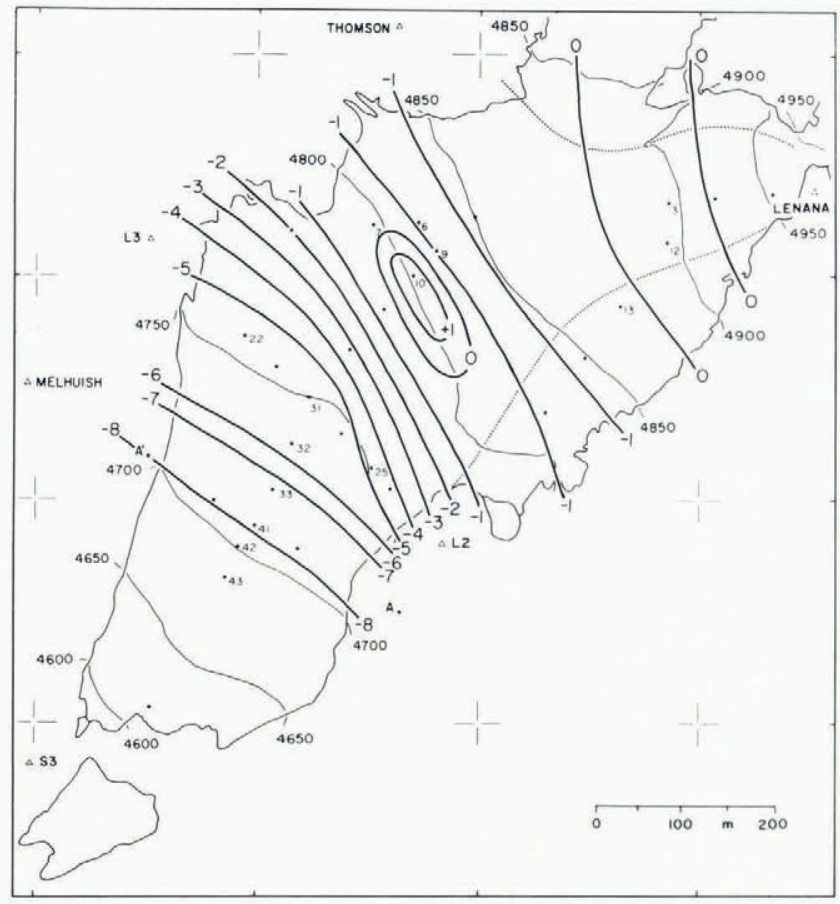

Fig. 2. Height change at stake network summed over the budget years 1978/79, 1979/80, 1980/81, 1981/82, in metres.

\section{FLOW PATTERN}

Maps have been published of the horizontal flow component at the surface of Lewis Glacier for various temporal intervals since January 1978 (Hastenrath and Kruss [1981], 1982; Kruss and Hastenrath, 1983). These maps indicate that the line chosen to be the longitudinal axis as shown in Figure 1 represents the central flow line reasonably well. In this present paper both the horizontal and vertical flow components are considered, but are limited to the central line (Fig. 1) so that conditions are presented in the longitudinal-vertical plane.

Whereas the earlier papers (Hastenrath and Kruss, [1981], 1982; Kruss and Hastenrath, 1983) concentrated on the horizontal velocity pattern at the surface, the vertical component of surface velocity is of particular interest in relation to the vertical net balance profile. This can be determined through the procedure described by Paterson (1969, p. 65-68) for the central flow line. The various EDM surveys (see previous section) provide the horizontal and vertical coordinates of the foot point of net balance stakes for the datum 25-26 January 1982. Moreover, the distance from a reference mark on the stake to the glacier surface is available from the net balance measurements. Thus, the vertical and horizontal displacement rates of the reference mark in an absolute coordinate system can be calculated. Let $\Delta z$ and $\Delta s$ denote the displacement of the stake mark in the vertical and horizontal directions, respectively, along the central line (Figs 1, 4, and 5), during the time interval $\Delta t$, with $\tan \alpha$ the surface slope. Then the 


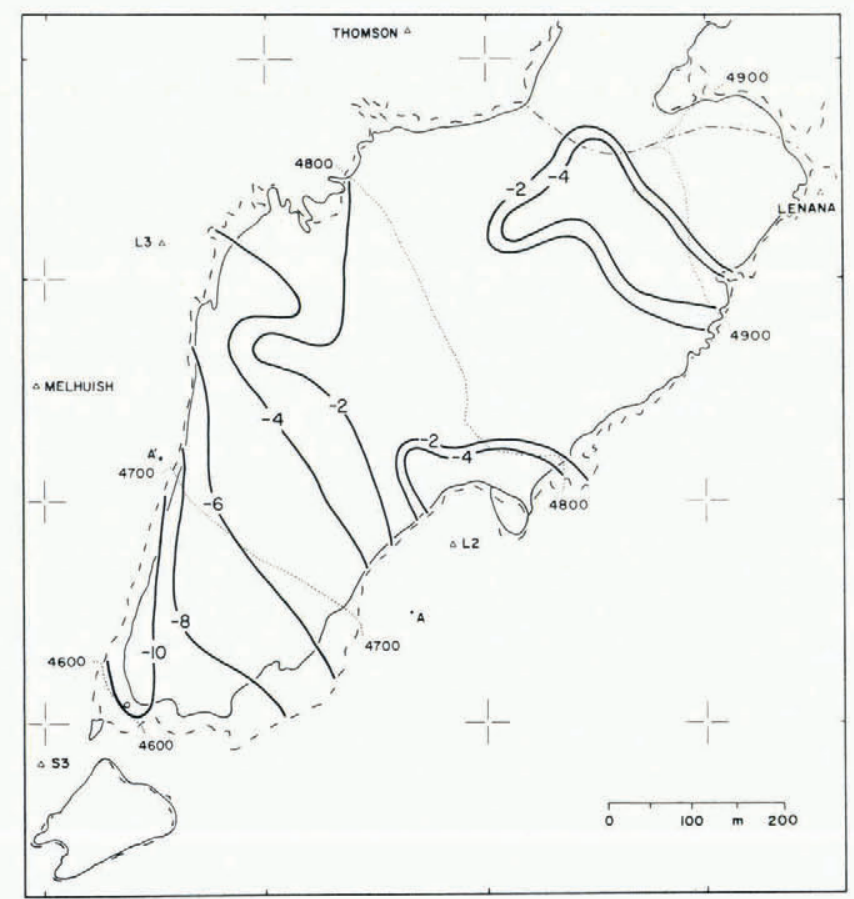

Fig. 3. Changes in ice thickness, March 1982 minus February 1978, in metres, as determined from the two airborne mappings. Ice rim in 1982 is shown as solid, and in 1978 as broken line. 1978 height contours are entered as thin dotted lines.

vertical component of surface flow counted positive downward is

$$
v=\frac{1}{\Delta t}(\Delta z-\Delta s \tan \alpha)
$$

and the horizontal component of surface flow in the plane described by the central line is

$$
u=\frac{\Delta s}{\Delta t} \text {. }
$$

The vertical and horizontal surface flow components were calculated for the net balance stakes located near the central line. For stakes 3, 10, 11, 31, and 43 evaluation was possible for the four-year period 25-29 January 1978 to 25-26 January 1982 . For stakes 21,32 , 41 , and 42 calculations were limited to the two-year interval 26-27 December 1979 to 29-30 December 1981 , and for stake 1 to the one-year period 25-29 January 1978 to December 1978-5 January 1979.

The resultant surface flow velocity in the longitudinal-vertical plane is depicted in Figure 4A. The flow vector is directed downward in the upper glacier and upward in the lower glacier. This feature is enhanced in Figure 4B, which is further relevant to the relationship between net balance, surface lowering, and flow dynamics discussed later (p. 400).

Although velocity measurements are as a rule limited to the surface, it is desirable to obtain a 


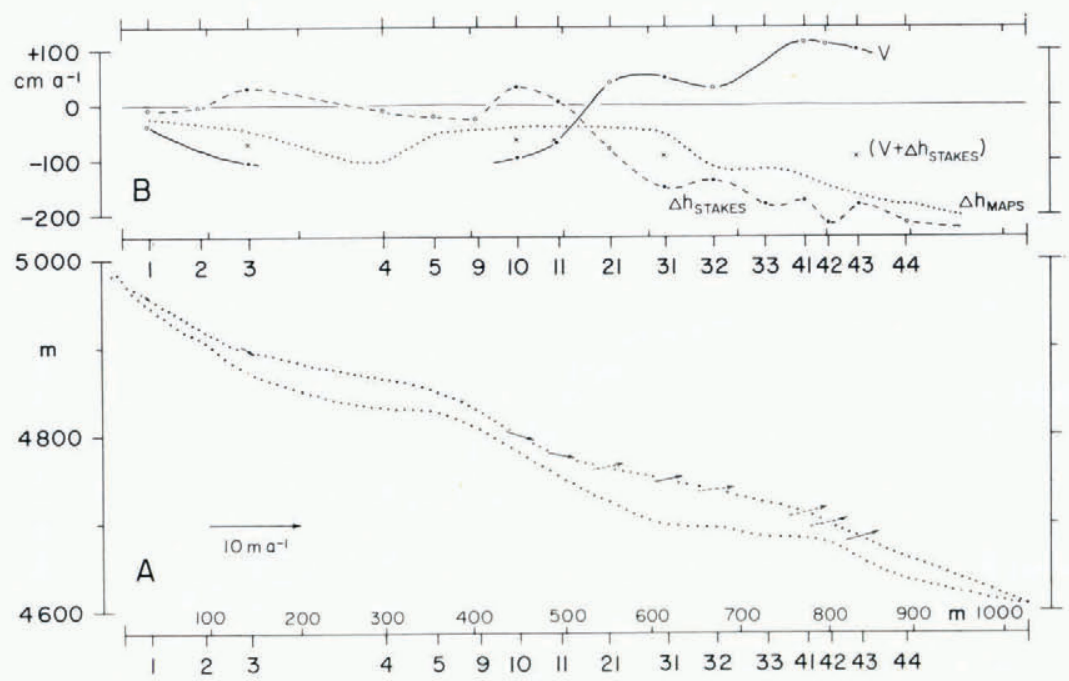

Fig. 4. Relation of vertical flow component, net balance, and surface lowering along the longitudinal axis of the glacier (dotted line in Fig. 1). Horizontal scale in metres is counted from the highest point of the glacier down the longitudinal axis and station numbers are as in Fig. 1.

(A) Surface flow velocity in longitudinal-vertical plane. Surface and bedrock topography are without vertical exaggeration. Velocity vectors in $m^{-1}$ are plotted at ten times the space scale in $m$ (i.e. $1 m^{-1}$ would be represented as a $10 \mathrm{~m}$ arrow). Arrows at stations 3, 10,11,31,43, refer to the four-year interval 25-29 January 1978 to 25-26 January 1982. Arrows at stations 21,32, 41, 42, belong to the two year period 26-29 December 1979 to 29-30 December 1981, and the arrow at station 1 is based on the one-year span 25-29 January 1978 to 28 December 1978-5 January 1979.

(B) Variation of vertical flow component, height changes at stake network, and lowering of surface topography along the longitudinal axis, in $\mathrm{cm} a^{-1}$. The vertical flow component $V$ is here plotted as positive upward from stations with information for the four-year and two (one) year periods described in (A), respectively. Height

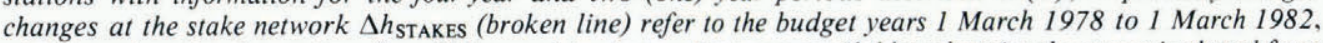
with dots denoting the stations for which complete observations are available; otherwise the curve is plotted from the map Figure 2. Observed time change of surface topography $\Delta h_{\text {MAPs }}$ (dotted line) is plotted for the interval February 1978 to March 1982, but dots denote stations for which values are for the two-year interval described in $(A)$ above. Crosses indicate the surface lowering $\left(V+\Delta h_{\mathrm{STAKES}}\right)$ obtained from the vertical velocity (solid line) and the height change at the stake network (broken line).

notion of the ice flow pattern in the interior of the glacier. This is illustrated in Figure 5 which was constructed as follows from the information contained in Figure 4A. The surface velocity vectors are decomposed into components parallel and perpendicular to the surface. The velocity component perpendicular to the surface is assumed to decrease in a linear fashion perpendicularly away from the surface to zero at the bedrock. Concerning the velocity component $V$ parallel to the surface, the decrease in the direction perpendicular to the surface is described by

$$
V_{\mathrm{s}}-V_{z}=\frac{n+2}{n+1} k(\operatorname{s\rho g} \sin \alpha)^{n} z^{n+1}
$$

where the subscripts $\mathrm{s}$ and $z$ refer to the surface and a perpendicular distance $z$ from the surface towards the bedrock (Budd, 1969, p. 193; Bhatt and others, [1982]). For $k$ and $n$ the values of $0.16 \mathrm{bar}^{-2} \mathrm{a}^{-1}$ and 2 respectively are used as in Bhatt and others ([1982]). For the stress shape factor $s$, values of 0.9 and 0.8 are adopted for the upper $(>4750 \mathrm{~m})$ and lower glacier, 


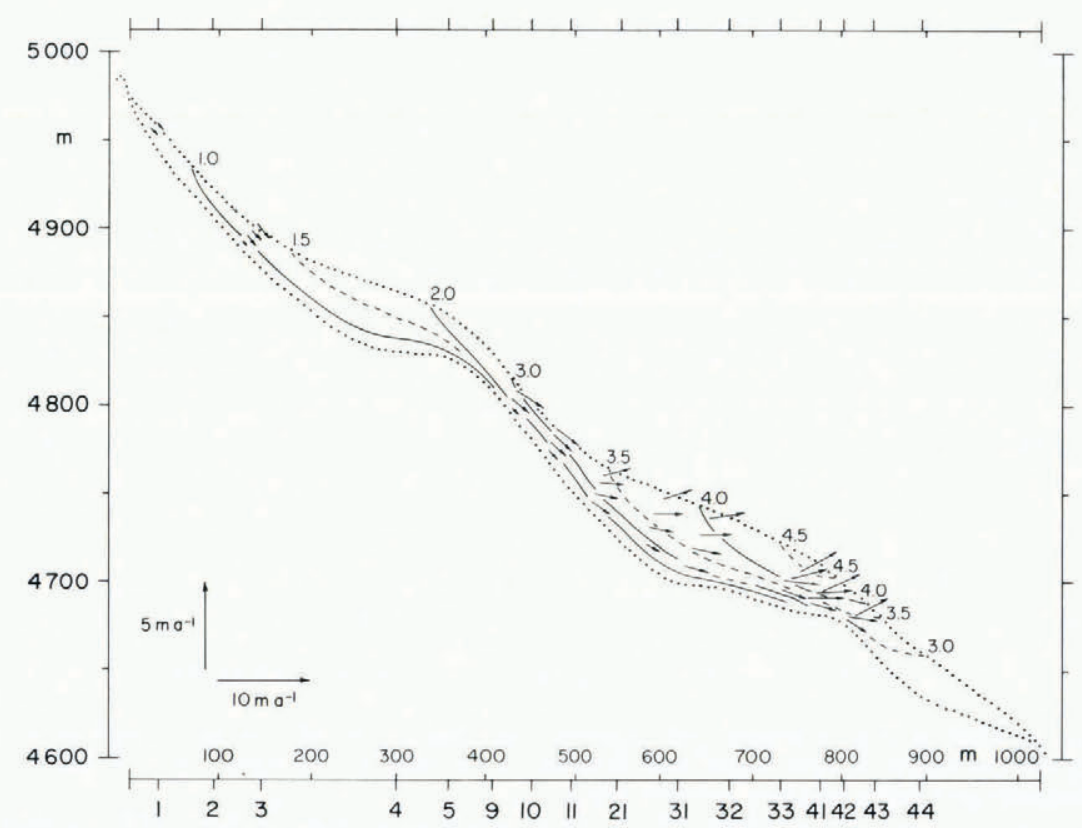

Fig. 5. Ice-flow pattern in longitudinal-vertical plane. Horizontal scale in metres is counted from the highest point of the glacier down the longitudinal axis and station numbers are as in Fig. 1. Dotted lines denote surface and bedrock topography, and solid and broken lines isotachs in $\mathrm{m} \mathrm{a}^{-1}$. Velocity vectors are plotted at ten times the space scale in $m$ (i.e. $10 \mathrm{~m} \mathrm{a}^{-1}$ would be represented as a $100 \mathrm{~m}$ arrow). Vertical exaggeration is double. Surface velocity vectors are the same as in part A of Fig. 4, but note the difference in orientation and length of arrows due to the vertical exaggeration (source: Fig. 4 and Equation (3)).

respectively. The values for ice density $\rho$ and gravitational acceleration $g$ are $0.9 \times 10^{3} \mathrm{~kg} \mathrm{~m}^{-3}$ and $9.806 \mathrm{~m} \mathrm{~s}^{-2}$. The surface slope $\tan \alpha$ is read from the $1: 2500$ map of surface topography (Hastenrath and Caukwell, 1979; see also Fig. 1). At each of the ten stations shown in Figures 4 and 5 the velocity components perpendicular and parallel to the surface were thus calculated for points at $0.25,0.50$, and 0.75 of the distance measured perpendicularly from the surface to bedrock. The resultant vectors are plotted in Figure 5 by direction and amount, together with the isotach pattern in the longitudinal-vertical plane.

As a complement to Figure 4, the longitudinal-vertical cross-section in Figure 5 shows the submergent flow in the upper and the emergent flow in the interior of the lower glacier, as well as the onion-skin arrangement of isotach sheets, with lowest values near bedrock and in the upper glacier, and a maximum near the surface in a portion of the lower glacier well above the terminus. This conceptually plausible flow pattern in the glacier interior (Paterson, 1965, p. 65) has seldom been quantitatively substantiated from observation, and never before for a glacier in the high mountains of the tropics.

Figure 5 is also pertinent to the age of ice within Lewis Glacier. Estimates of representative residence times are desired in relation to the secular glacier recession (Hastenrath, 1975) and in support of climatic ice-core studies (Thompson and Hastenrath, [1982]). With this motivation, a "bulk residence time" of ice in the upper glacier was first calculated by dividing the ice volume upward of the line L2-L3 near $4750 \mathrm{~m}$ (Fig. 1) by the estimated mass flux across a vertical plane at that line, which yielded a value of about 150 years (Hastenrath, 1975). The 
comprehensive field program carried out on Lewis Glacier since the beginning of 1978 permits an update of this exercise. For the datum February 1978, the ice volume upward of the $4750 \mathrm{~m}$ contour is estimated at about $3 \times 10^{6} \mathrm{~m}^{3}$ (Bhatt and others, [1982]). The maximum mass flux of $3 \times 10^{4} \mathrm{~m}^{3} \mathrm{a}^{-1}$ is found at about this elevation (Hastenrath and Kruss, [1981], 1982; Kruss and Hastenrath, 1983). The ratio yields a "bulk residence time" in the upper glacier ( $>4750 \mathrm{~m})$ of about 100 years.

As a complement to these bulk considerations, Figure 5 offers a better appreciation of trajectories and age of ice in the interior of Lewis Glacier. For the following evaluation assume near steady-state conditions, so that trajectories coincide approximately with streamlines. As a first example, consider an ice element at an initial surface location near $300 \mathrm{~m}$ on the longitudinal axis, or somewhat above station 4 . The trajectory for this ice element is characterized by submergence, a closest proximity to the bedrock between 400 and $500 \mathrm{~m}$ (around station 10), then emergence and a surfacing near $600 \mathrm{~m}$ or somewhat above station 31 . Integration by finite steps between isotachs yields a total travel time from the initial location to the final surfacing location which is of the order of a century. As a second example, consider an ice element in an initial surface location at $125 \mathrm{~m}$ on the longitudinal axis, or somewhat above station 3. Over its trajectory in the upper glacier the element submerges, coming closest to the bedrock around $400 \mathrm{~m}$ on the longitudinal axis. The longitudinal coordinate of $500 \mathrm{~m}$, which corresponds approximately to the $4750 \mathrm{~m}$ surface contour, is reached after nearly four centuries. The trajectory surfaces below the longitudinal coordinate of $700 \mathrm{~m}$ or near station 33 , with a total travel time of four to five centuries.

The travel time from a surface location in the uppermost extremity of the glacier to the $4750 \mathrm{~m}$ surface contour of nearly four centuries should be compared with the "bulk residence time" for ice in the upper glacier which is of the order of one century as estimated above. Note that for the ice elements located at the surface along the longitudinal axis, the travel time would average around two centuries (being four centuries for the upper extremity of the glacier and zero at the $4750 \mathrm{~m}$ surface contour). Moreover, the ice flows faster along the centerline than to either side of it. With these qualifications, the travel time derived from Figure 5 and the estimate of "bulk residence time" do not seem inconsistent.

The above considerations also point to the inevitable shortcomings of residence time calculations. Lewis Glacier is not in steady state, so that flow lines differ from trajectories Furthermore, at earlier epochs in this century, the glacier was longer and thicker, so that the travel distance from the upper extremity of the glacier to the snout region was longer, but the faster flow had the reverse effect on the travel time. Finally, the time scale of climate and glacier variations is comparable with or smaller than the range of typical residence times. All these factors hamper the estimation of residence time from flow considerations.

\section{Mass CONTINUITY}

The maps of 1978-82 height change measured with respect to the stake network (Fig. 2) and of topography change documented from the repeated airborne mappings (Fig. 3) show differentials of similar magnitude and largest negative values in the lower glacier, but the patterns differ in detail. This is in part due to the spatial resolution of the stake network, but in part to the redistribution of mass related to the flow dynamics. The latter factor is also indicated in Table I, in that for most of the upper glacier the height decrease $H_{\mathrm{m}}$ derived from the 1978 and 1982 


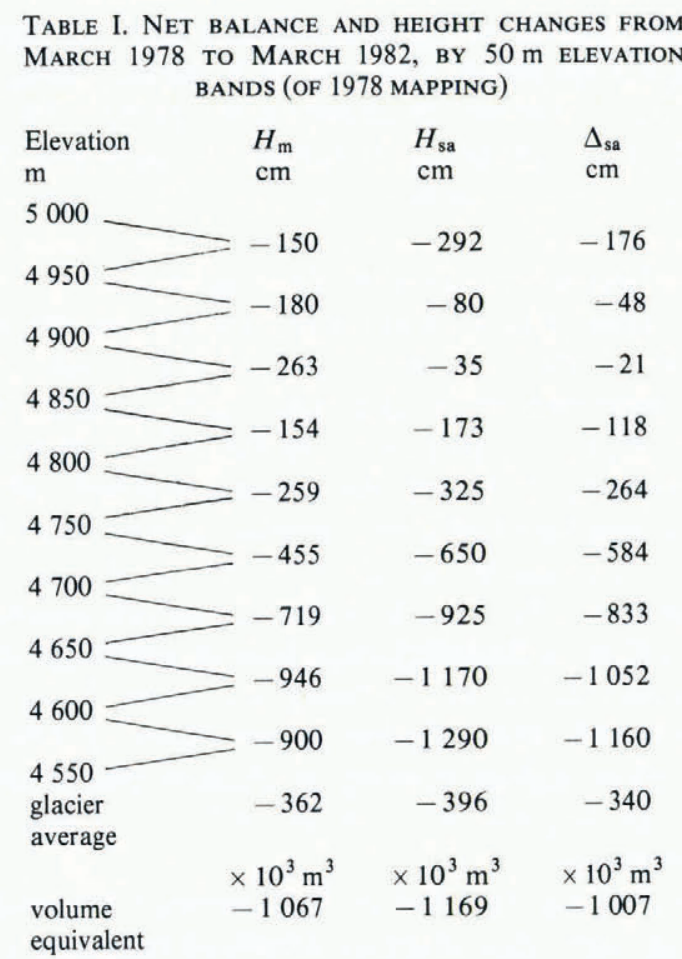

mappings is larger than that obtained from the stake network, $H_{\mathrm{sa}}$, whilst the reverse is true for the lower glacier. For the glacier as a whole the two independent techniques yield thickness or volume decreases which agree closely within plausible error tolerances. The close agreement between the two independent methods indicates that melting at depth greater than the lowest surface elevation respective to the stake, in the course of the year, is of subordinate importance.

The relationship between surface lowering, net balance, and flow dynamics suggested from the comparison of maps (Figs 2 and 3) and Table I, is in terms of the pertinent processes substantiated in Figure 4, especially part B. The vertical component of ice flow at the surface is downward in the upper (upward in the lower) glacier. This corresponds to surface velocity vectors plotted in the longitudinal-vertical cross section in part A of Figure 4. Returning to part B of Figure 4, net balance over the four-year interval 1978-82 is negative at all elevations along the longitudinal axis, with losses increasing towards the lower glacier. The sum of these two quantities, but expressed as geometric distance rather than in liquid-water-equivalent units, is expected to represent the change in surface topography over the four-year interval 1978-82. The available data allowed this evaluation for five of the stations. These calculations should be compared with the observed surface lowering, as documented by the 1978 and 1982 mappings of the glacier topography. The two independent approaches agree in major respects: (a) negative values are obtained at all stations, with surface lowering increasing from the upper towards the lower glacier; (b) the surface lowering exceeds the negative net balance in the upper, but is less than the net balance effect in the lower glacier, thus demonstrating the role of vertical velocity, and mass redistribution through flow dynamics. The values of surface lowering obtained by the 
two independent methods differ, which may in part be due to the error tolerances in field measurements and evaluation procedures. However, it is apparent from part B of Figure 4 that in the upper glacier the surface lowering calculated from vertical flow velocity and net balance slightly exceeds the value documented by the 1978 and 1982 mappings, whereas the reverse is the case in the lower glacier. These systematic departures may be due to the fact that the flow is confluent in the upper glacier where its bed narrows down-stream, whilst in the lower glacier diffluence is favored both by the widening of the valley and the upward-convex bedrock topography apparent in the central portion of the snout region. Part B of Figure 5 thus underlines the important role of flow dynamics and mass redistribution in modulating the effect of net balance on surface topography.

\section{Conclusions}

The observation program provides a quantitative picture of submergent ice flow in the upper and emergent ice in the lower glacier of the order of $1-2 \mathrm{~m} \mathrm{a}^{-1}$, and allows an estimate of a few centuries for the representative residence time of ice in Lewis Glacier. The "glaciological" (stake) and "geodetic" methods (Hoinkes, 1970) yield within error tolerance the same magnitude of about $10^{6} \mathrm{~m}^{3}$ for the ice loss of the glacier as a whole over the interval 1974-78. However, the reported mappings of surface topography document for the upper (lower) glacier a larger (smaller) surface lowering than expected from the stake network. This contrast between the upper and lower glacier is consistent with the quantitative assessment of the vertical motion field.

Consistency between internal flow conditions and the "glaciological" (stake) and "geodetic" methods of glacier mass-budget determination (Hoinkes, 1970) is expected from theory, but the concurrent application of these independent techniques has rarely been accomplished, even for the logistically comfortable mountain regions of the mid-latitudes. It is intended to continue the long-term observation program on this mountain glacier under the Equator as a contribution to international efforts at global environment monitoring.

\section{ACKNOWLEDGMENTS}

This study was supported through U.S. National Science Foundation Grant EAR79-23897. The United Nations Environment Programme supported the Expedition in 1981/82, which brought four years of continuous glacier and climate monitoring to an interim fruition. Conversations with the late Herfried Hoinkes and with Phillip Kruss are gratefully acknowledged. The research is authorized by the Office of the President, Republic of Kenya.

MS. received 16 November 1982 and in revised form 28 January 1983

\section{REFERENCES}

Bhatt, N., and others. [1982.] Ice thickness determination at Lewis Glacier, Mount Kenya: seismology, gravimetry, dynamics, by N. Bhatt, S. Hastenrath, and P. [D.] Kruss. Zeitschrift für Gletscherkunde und Glazialgeologie, Bd. 16, Ht. 2, 1980, p. 213-28.

Budd, W. F. 1969. The dynamics of ice masses. ANARE Scientific Reports. Ser. A(IV). Glaciology. Publication No. 108. 
Caukwell, R. A., and Hastenrath, S. 1977. A new map of Lewis Glacier, Mount Kenya. Erdkunde, Bd. 31, Ht. 2, p. 85-87.

Caukwell, R. A., and Hastenrath, S. 1982. Variations of Lewis Glacier, Mount Kenya, 1978-82. Erdkunde, Bd. 36, Ht. 4, p. $299-303+$ map as Beilage X to Bd. 36.

Hastenrath, S. 1975. Glacier recession in East Africa. (In Proceedings of the WMO-IAMAP symposium on long-term climatic fluctuations, Norwich, 18-23 August 1975. Geneva, World Meteorological Organization, p. $135-42$. (WMO No. 421.))

Hastenrath, S., and Caukwell, R. A. 1979. Variations of Lewis Glacier, Mount Kenya, 1974-78. Erdkunde, Bd. 33, Ht 4, p. 292-97.

Hastenrath, S., and Kruss, P. D. [1981.] Dynamics of crevasse pattern at Lewis Glacier, Mount Kenya. Zeitschrift für Gletscherkunde und Glazialgeologie, Bd. 15, Ht. 2, 1979, p. 201-07.

Hastenrath, S., and Kruss, P. D. 1982. On the secular variation of ice flow velocity at Lewis Glacier, Mount Kenya, Kenya. Journal of Glaciology, Vol. 28, No. 99, p. 333-39.

Hastenrath, S., and Patnaik, J. K. 1980. Radiation measurements at Lewis Glacier, Mount Kenya, Kenya. Journal of Glaciology, Vol. 25, No. 93, p. 439-44.

Hoinkes, H. C. 1970. Methoden und Möglichkeiten von Massenhaushaltsstudien auf Gletschern. Ergebnisse der Messreihe Hintereisferner (Ötztaler Alpen) 1953-1968. Zeitschrift für Gletscherkunde und Glazialgeologie, Bd. 6, Ht. 1-2, p. 37-90.

Kruss, P. D., and Hastenrath, S. 1983. Variation of ice velocity at Lewis Glacier, Mount Kenya, Kenya: verification midway into a forecast. Journal of Glaciology, Vol. 29, No. 101, p. 48-54.

Paterson, W. S. B. 1969. The physics of glaciers. Oxford, etc., Pergamon Press. (The Commonwealth and International Library. Geophysics Division.)

Thompson, L. G., and Hastenrath, S. [1982.] Climatic ice core studies at Lewis Glacier, Mount Kenya. Zeitschrift für Gletscherkunde und Glazialgeologie, Bd. 17, Ht. 1, 1981, p. 115-23. 